\title{
University Students' Preferable Types of Teacher Humor in English Classes
}

\author{
Pham Trut Thuy, ${ }^{1}$ Le Thanh Thao ${ }^{2 *}$ \\ ${ }^{1,2}$ Nam Can Tho University, Viet Nam
}

\begin{abstract}
Article Information
Received 20 August 2021

Accepted 29 September 2021

Published October 29, 2021

Abstract

The current study aimed to explore what types of teacher humor EFL students prefer in their classes. The study was designed as a mixed-method approach, using questionnaires and semi-structured interviews to collect data in two different Vietnamese universities. One hundred fifty-eight university students responded to the survey, and eight out of them were recruited as the participants for the interviews. The study results revealed that the types of jokes $(M=4.41)$, riddles $(M=4.08)$, and language play $(M=4.15)$ were most favored. Besides, the participants' demographic information, including their gender and majors, affected their preferable types of teacher humor. Specifically, males showed more positive attitudes towards teacher humor than their counterparts. In terms of students' majors, there were differences between non-English majors and English-majored students' perceptions of irony, teasing, language play, visual and physical humor. Regarding the students' positive attitudes towards teacher humor, EFL teachers should learn more about valuable strategies for using teacher humor in their classes due to the fact that they do not need to have a sense of humor to use it effectively.
\end{abstract}

Keywords: $\quad$ teacher's humor; EFL students' perceptions; forms of humor; the Mekong Delta of Vietnam

\section{Introduction}

In the globalization era, English has become an international language. Therefore, teaching English as a foreign language (EFL) is compulsory in the Vietnamese educational context at all education levels. The Vietnamese government has made remarkable efforts to enhance Vietnamese students' English competencies, and Vietnam's National Foreign Language 2020 Project is one of the examples. However, the project results have been under-

*Corresponding Author: Le Thanh Thao (lethanhthao110294@gmail.com) 168 Nguyễn Văn Cừ nối dài, An Bình, Ninh Kiều, Cần Thơ, Vietnam expected due to recognizable reasons, such as insufficient academic staff, low-quality infrastructures and facilities, and students' motivation. Significantly, teacher-related factors are considered the leading causes of these results.

Among teacher-related factors, including personalities, knowledge, attitudes, abilities, etc., the influence of teacher humor is overlooked on its contributions to EFL teaching and learning. However, several preceding studies have explored the teacher humor functions, such as sociological, 
anthropological, psychological, philosophical, and linguistic features (Dynel, 2009). In the educational context, teacher humor has been considered as a pedagogical tool increasing instructional effectiveness (Englert, 2010), lowering students' anxiety, creating a relaxed classroom environment (Neuliep, 1991; Petraki \& Nguyen, 2016), motivating students in learning (McCroskey et al., 2006), improving students' learning (Baringer \& McCroskey, 2000), establishing collaborative teacherstudent interaction (Petraki \& Nguyen, 2016), and even keeping students thinking (Torok et al., 2004). Nonetheless, EFL teachers avoid using it in their English classes since teacher humor has some drawbacks, such as disparaging others, controlling and mocking nonconforming behaviors, exhibiting power or status differences, or suppressing undesired actions (Martin, 2010). However, the query on using teacher humor effectively in EFL classes has not received much attention from educators. Due to the teacher humor potentials, this current study aims to investigate EFL students' preferable types of teacher humor in their English classes.

\section{Definitions of Humor}

The word 'humor' is derived from "umor" referring to "bodily fluid" controlling human health and feelings. There has been a drastic change defining the conceptualization of humor. Curnow et al. (2005) simplified the definition of humor as what makes people laugh. Bekelja et al. (2006) stated that humor is what communicators feel funny or amusing. Tuncay (2007) defined humor as the ability to understand the language and words according to their use, meanings, subtle nuances, the underlying cultures, implications, and verbal messages. Apte (1985) distinguished two distinctive elaborations on humor, including potential stimuli sources and behavioral responses. In the study by Martin (2010), people use humor to exchange questions, answers, comments, remarks, or explanations throughout classroom interactions. In this current study, humor is defined as what EFL teachers and their students feel funny and delighted about throughout the learning duration. As a result, teacher humor is what the teachers purposefully use to make their students laugh to enhance the teaching and learning quality.

\section{Forms of Humor}

Norrick (2003) indicated that it is difficult to identify the differences amongst many teacher humor styles since it is often faded into each utterance in a conversation. These types have been named irony, teasing, banter, language play, jokes, riddles, and other forms (Fadel \& AlBargi, 2018).

\section{Irony}

Irony refers to the employment of implicit or ambiguous speeches or utterances that have double meanings (Fadel \& Al-Bargi, 2018). Sarcasm, a subtype of irony, is more likely to be used for aggressive purposes in speech or to harm the sentiments of its target than other simple kinds of irony.

\section{Teasing}

Teasing is incitement, which is created purposely and is usually accompanied by whimsical, casual talks to debate something relevant to the target (Keltner et al., 2001). Despite the risk of bringing transgressions, Boxer and Cortés-Conde (1997) proved that 
teasing could have positive influences by producing intimacy as it works in consolidating people or clarifying knowledge.

\section{Banter}

Banter, as a term, is employed to specify the synopses where teasing happens back and forth, appearing in a verbal match-up (Goatly, 2012). The foremost aim of banter is to build a social bond through acceptance-friendship maneuverings; nevertheless, it becomes worthless when the beneficiary does not acknowledge (Fadel \& Al-Bargi, 2018).

\section{Language Play}

Language play is noticed as a deliberate reproduction or alterations of linguistic patterns like syntactic, phonologic, or lexemes exemplars (Belz, 2002). Language play is the usual humor within the EFL classroom setting since twiddling with words and their definitions can be an ordinary interplay for students in a particular context (Tarone, 2005).

\section{Joke}

Morrison (2012) characterized a joke as a short story or word series or communicated with the intent of being laughed at or found humorous by the listener or reader. Schmitz (2002) chartered jokes into three divisions, shared jokes, culture jokes, and linguistic jokes. Notably, Shade (1996) clarified some unsuitable varieties of humor within the classroom context, such as sexual, ethnical /racial, religious, hostile, and demeaning to men/women jokes.

\section{Riddles}

Fadel and Al-Bargi (2018) defined riddles as a word game that has a question-answer format involving an enigma, a puzzling fact, which is similar to a joke and usually has a surprisingly funny answer. In classrooms, riddles should be associated with the subject matter to encourage students to dissect and debate ideas by using their higher-order thinking abilities to resolve them (Shade, 1996).

\section{Others}

Besides the types of teacher humor above, Fadel and Al-Bargi (2018) also mentioned others including, visual humor and physical humor.

\section{Related studies}

Petraki and Nguyen (2016) examined Vietnamese university teachers' perceptions of teacher humor in EFL classes, practices of humor use, and preferred types of teacher humor. The authors employed an ethnographic approach, combining observations, field notes, and interviews to collect data from 30 universities working in three different universities in a large city in Vietnam. The study results indicated that Vietnamese teachers were aware of the teacher humor benefits in their English classes. Additionally, they often used humorous comments, jokes, and funny stories to lighten the atmosphere and increase their immediacy.

Kim and Park (2020) explored the types of verbal humor affecting the interaction between teachers and their students in elementary-level English classes in Korea. The authors used eighty-three videotaped regular English classes and seven teacher interviews to collect data. The study results revealed that lack of English proficiency hindered the effectiveness of teacher humor in the research context. Wordplay was the most frequently used type of 
teacher humor. Besides, both teacher and student participants often used teasing to distract and gather attention. Moreover, the senior students used jokes to save face. Regarding teacher participants, the females shared their anecdotes while the males did not. Hyperbole and self-deprecation were indicated as the least frequently used types among all proposed types of teacher humor.

Fki (2021) conducted a study to investigate lecturers' and learners' perceptions on humor use in Tunisian tertiary classrooms, focusing on English major. It aimed to explore the types and frequency of humor use in EFL classes. Moreover, the study checked whether there was any difference between lecturers' and students' perceptions of teacher humor in EFL classes. Employing a mixed-method approach, the study used questionnaires and semistructured interviews to gather data for analysis. Teachers' gender did not affect the frequency of humor use in their classes. Most participants were aware of the contributions of teacher humor in EFL classes. Besides, the participants' preferred using verbal, spontaneous, and relevant humor types.
Unlike the aforementioned studies, this current study primarily focused on investigating EFL university students' preferable teacher humor in their classes. Besides, the study examined whether the students' demographic information affected their preferable types of teacher humor in their English classes. As a consequence, the two main research objetives are to find out what EFL university students' preferable types of teacher humor are and whether EFL university students' demographic information affects their preferable types of teacher humor.

\section{Method}

The study employed a descriptive mixedmethod approach a descriptive mixed-method approach. Data were collected using questionnaires and semi-structured interviews. The questionnaires were used to gain a comprehensive picture of the issue. They were manipulated to guarantee the validity and reliability of the data wherein the 158 university EFL students in the Mekong Delta, Vietnam. Table 1 presents the participants' information.

Table 1.

Brief information about the participants for the questionnaire

\begin{tabular}{llr}
\hline & \multicolumn{1}{c}{ Variable } & Number \\
\hline \multirow{2}{*}{ Gender } & Male & 48 \\
\cline { 2 - 3 } & Female & 110 \\
\hline \multirow{2}{*}{ Major } & English-Majored & 84 \\
\cline { 2 - 3 } & Non-English-Majored & 74 \\
\hline
\end{tabular}

The questionnaires concentrate on investigating the participants' preferable types of teacher humor. It comprises eight items rated on a five-point Likert scale $(5=$ strongly agree, 4=agree, 3=neutral, 2=disagree, $1=$ strongly disagree).
The survey was translated into Vietnamese, the participants' mother tongue, to avoid ambiguity and misinterpretation of the language because the study was conducted in a Vietnamese context. Moreover, the Vietnamese transcription questionnaire 
empowers the respondents to comprehend the items' meanings fully and then implement reliable answers. The researchers first turned the questionnaires into Vietnamese. Then, two TESOL colleagues were kindly invited to translate the Vietnamese version into English to examine whether these English versions were equivalent to the original English ones or not.

The questionnaires were respectively distributed via Google Form to 50 university EFL students who would not participate in the actual research. Cronbach's alpha, computed for the questionnaire $(\alpha=.95)$, indicated high internal consistency, which means the questionnaires could be applied to collect the actual data $(0.7 \leq \alpha \geq 0.95)$.

The fully revised questionnaires were then administered to 158 students via Google Form. Before delivering the questionnaires to the participants, the researchers explained the topic content and the scope of the study to the students to ensure that the participants gained a sweeping vista of the research topic. The participants were encouraged to complete the questionnaires as soon as possible. After a month, the data were fully collected. The results of the Scale Test confirmed the reliability coefficient of the questionnaire $(\alpha=.93)$.

The researchers sent invitations to sixteen participants $(10 \%)$ to participate in the interviews. However, eight out of sixteen refused to participate due to personal reasons. Therefore, the semi-structured interviews were employed with the participation of eight out of 158 participants. Table 2 shows the interviewees' demographic information.

Table 2.

Participants for interviews

\begin{tabular}{lcccccccc}
\hline & A & B & C & D & E & F & G & H \\
\hline Gender & Female & Female & Male & Male & Female & Female & Male & Male \\
\hline Major & Majored & Majored & Majored & Majored & Non-M & Non-M & Non-M & Non-M \\
\hline Mean & 1.63 & 3.89 & 2.68 & 4.01 & 2.98 & 4.85 & 3.21 & 5.00 \\
\hline
\end{tabular}

The researchers recruited the participants according to their backgrounds, including gender (four females and four males), major (four English-majored and four non-English major students), and mean score (two females gaining two lowest mean scores, two males getting two lowest mean scores, two females achieving highest mean scores, and two male students having highest mean scores in each group according to their major). Even though the interviewees were under $10 \%$ of the principal participants, the primary purpose of interviews was to understand the questionnaire results. Therefore, the research team was confident enough in the significance of the qualitative data findings.

The interviewing questions mainly focused on the participants' preferable types of teacher humor in their English classes. Moreover, the interviewers used supporting questions with "WH-questions" and "Yes or No questions" to elicit their ideas about why they favored particular types of teacher humor. The followup questions helped researchers understand underlying reasons for their reasons. During the interviews, Vietnamese as the learner participants' mother tongue was used to help 
them respond comprehensively and comfortably. The interviews were recorded and note-taken under the permission of the interviewees. After that, they were transcribed into English and analyzed based on themes in the framework of the current study.

Besides, in the statistical analysis, the research team used the scale ranges proposed by Oxford (1990) to interpret participants' preferred types of teacher humor in EFL classes. On the scale, four levels, including low (from 1.0 to 2.4), medium (from 2.5 to 3.5 ), high (from 3.6 to 4.4 ), and very high (from 4.5 to 5.0 ), are suggested. For all analyses, differences were considered significant if $p$-value $<.05$, and vice versa.

\section{Findings and Discussions}

\section{EFL Students' Preferable Types of Teacher Humor in EFL Classes}

A Descriptive Statistic Test was run to examine the average of EFL students' preferable types of teacher humor in EFL classes. Table 3 displays the test results.

Table 3.

EFL students' preferable types of teacher humor

\begin{tabular}{lccccc}
\hline \multicolumn{1}{c}{ Forms } & $\mathbf{N}$ & Minimum & Maximum & Mean & SD \\
\hline Irony & 158 & 1.00 & 5.00 & 3.70 & 1.08 \\
\hline Teasing & 158 & 1.00 & 5.00 & 3.82 & 1.01 \\
\hline Banter & 158 & 1.00 & 5.00 & 3.21 & 1.31 \\
\hline Language play & 158 & 1.00 & 5.00 & 4.15 & .82 \\
\hline Joke & 158 & 1.00 & 5.00 & 4.41 & .74 \\
\hline Riddles & 158 & 1.00 & 5.00 & 4.08 & .96 \\
\hline Visual humor & 158 & 1.00 & 5.00 & 3.72 & 1.15 \\
\hline Physical humor & 158 & 1.00 & 5.00 & 3.74 & 1.05 \\
\hline Total & $\mathbf{1 5 8}$ & $\mathbf{1 . 6 3}$ & $\mathbf{5 . 0 0}$ & $\mathbf{3 . 8 5}$ & $\mathbf{. 7 3}$ \\
\hline
\end{tabular}

The mean score of the EFL students' preferable forms of teacher humor in EFL classes was relatively high ( $M=3.85)$. Then, a One-Sample T-Test was run to check whether the mean score $(M=3.85)$ is different from the test value 3.5 , an accepted value for medium perception (Oxford, 1990). The test results showed a significant difference between the mean score $(M=3.85)$ and the 3.5 test value $(p=.00)$. It means that the EFL students were delighted with the proposed types of teacher humor in the current study. It can be inferred that the students highly perceived the benefits of teacher humor in their English learning.
Many previous studies have explored the benefits of teacher humor in English learning and teaching. Teacher humor, when appropriately used, can increase instructional effectiveness (Englert, 2010), lower students' anxiety, create a relaxed classroom environment (Neuliep, 1991), motivate students in learning (McCroskey et al., 2006), improve students' learning outcomes (Baringer \& McCroskey, 2000), establish collaborative teacher-student interaction (Petraki \& Nguyen, 2016), and even keep them thinking (Torok et al., 2004). 
Among the eight proposed types of teacher humor, the students preferred the type of joke the most ( $M=4.41)$. Student $H$ said,

"My teacher is absolutely a humorous person. Whenever he uses his jokes, my friends and I laugh a lot. Therefore, I really enjoy the classes. Moreover, the exciting atmosphere also increases my motivation for continuing the lesson." $(\mathrm{H}$; Male; Non-English Major Student; $M=5.00$ )

The Tunisian EFL students in the study by Fki (2020) also favored teachers' jokes. Jokes can lighten the classroom atmosphere and increase the teachers' immediacy. Petraki and Nguyen (2016) found that one of the Vietnamese teachers preferred humor was joke/joking due to the earlier benefits. The use of teacher's jokes might be effective in the Vietnamese context since both Vietnamese students and teachers preferred this type of teacher humor.

On the other hand, the students resisted banter in their English classes ( $M=3.21)$. In the interviews, the students were confused about the benefits of banter in their English classes. Student $C$ stated,

"I love making fun of my English teacher, and I really enjoy it when he does it to me. However, when something like banter is overused, it becomes very annoying. When it happens, I feel like I look too ridiculous." (C; Male; EnglishMajored Student; $M=2.68$ )
Although Bonacchi (2018) remarked on the importance of banter in establishing, confirming, and strengthening friendly relations, the current participants seemed not to recognize these contributions in their English classes. According to Technau (2017), a banter utterance as a combination of an impolite or even aggressive structure are often far from clear and can wildly differ the listeners' perceptions and cause misunderstandings. Agreeably, the person being targeted by banter may end up being humiliated. Therefore, using banter can be considered a risky behavior (Technau, 2017). Vietnamese people, deeply influenced by traditional Confucianism, tend to avoid behaviors considered inelegant and indecent.

\section{Influence Level of Students' \\ Demographic Information on Their Preferences of Teacher Humor}

The current study employed an Independent Sample T-test to check whether there was any significant difference between male and female university students' perceptions of teacher humor forms. Table 4 illustrates the test results.

Table 4.

EFL students' preferable types of teacher humor considering their gender

\begin{tabular}{lcccccc}
\hline \multicolumn{1}{c}{ Forms } & Gender & $\mathbf{N}$ & Mean & SD & SEM & $\mathbf{p}$ \\
\hline \multirow{2}{*}{ Irony } & Male & 48 & 4.02 & 1.08 & .16 & \multirow{2}{*}{01} \\
\cline { 2 - 7 } & Female & 110 & 3.56 & 1.05 & .10 & \\
\hline \multirow{2}{*}{ Teasing } & Male & 48 & 4.21 & .97 & .14 & \multirow{2}{*}{00} \\
\cline { 2 - 7 } Banter & Female & 110 & 3.65 & .98 & .09 & \\
\cline { 2 - 6 } & Male & 48 & 3.71 & 1.38 & .20 & \multirow{2}{*}{00} \\
\cline { 2 - 7 } & Female & 110 & 2.99 & 1.22 & .12 & \\
\hline \multirow{2}{*}{ Language play } & Male & 48 & 4.38 & .79 & .11 & .02 \\
\hline
\end{tabular}




\begin{tabular}{|c|c|c|c|c|c|c|}
\hline & Female & 110 & 4.05 & .81 & .08 & \\
\hline \multirow{2}{*}{ Joke } & Male & 48 & 4.60 & .61 & .09 & \multirow{2}{*}{.03} \\
\hline & Female & 110 & 4.33 & .78 & .07 & \\
\hline \multirow{2}{*}{ Riddles } & Male & 48 & 4.44 & .90 & .13 & \multirow{2}{*}{.00} \\
\hline & Female & 110 & 3.92 & .94 & .09 & \\
\hline \multirow{2}{*}{ Visual humor } & Male & 48 & 4.10 & 1.12 & .16 & \multirow{2}{*}{.01} \\
\hline & Female & 110 & 3.55 & 1.12 & .11 & \\
\hline \multirow{2}{*}{ Physical humor } & Male & 48 & 4.02 & 1.02 & .15 & \multirow{2}{*}{.03} \\
\hline & Female & 110 & 3.62 & 1.04 & .10 & \\
\hline \multirow{2}{*}{ Total } & Male & 48 & 4.18 & .75 & .11 & \multirow{2}{*}{.00} \\
\hline & Female & 110 & 3.71 & .68 & .07 & \\
\hline
\end{tabular}

According to the test results, the male students showed more positive attitudes towards all proposed teacher humor types than their counterparts (Mmale > Mfemale; $p<.05$ ). In other words, teacher humor would be highly accepted in English classes where male students are more dominant than females in the current research context, according to the current findings.

In the interviews, the male students also agreed with the questionnaire results. Specifically, Student D said,

"Yeah, I think teacher humor will be accepted by us [males] more than it will be by the girlfriends. In my opinion, the females are more sensitive than us." (D; Male; English-Majored Student; $M=4.01$ )

On the other hand, the female interviewees shared the reasons they did not highly welcome teacher humor. Student E stated,

"I think teacher humor is good due to its benefits. I am aware of these benefits; it, however, causes many problems when being inappropriately used. It easily becomes graceless." (E; Female; NonEnglish Major Student; M=2.98)

Student A, another female, stated,

"I have had so many boyfriends, and they often use banter, which has gone way beyond the pale.
I mean the banter has become unacceptable." ( $A$; Female; English-Majored Student; $M=1.63$ )

The results aligned with the study by AbdAli et al. (2016). Specifically, male students' positive attitudes towards teacher humor were higher than female ones in the Iraqi educational context. For the explanations, Moroschan et al. (2009) stated that males are likely to enjoy humor or even produce humor to deal with difficulties or lower tension and anxiety. Moreover, Liu (2012) claimed that females often respond to humor carefully to avoid being derisive and immodest. Vietnamese women are characterized by four virtues: diligent work, tasteful appearance, proper speech, and good morals. Especially in the proper speech virtue, Vietnamese women are taught to use gentle and charming words and speak politely and smartly. Therefore, the female students' resistance to humor showed Vietnamese women's cultural and intellectual capital.

Next, an Independent Sample T-test was administered to examine whether there was any significant difference between Englishmajored and non-majored university students' preferable types of teacher humor. Table 5 illustrates the test results. 
Table 5.

EFL students' preferable types of teacher humor in light of their major

\begin{tabular}{|c|c|c|c|c|c|c|}
\hline Forms & Majors & $\mathbf{N}$ & Mean & SD & SEM & $\mathbf{p}$ \\
\hline \multirow[t]{2}{*}{ Irony } & E-Majored & 84 & 3.54 & 1.00 & .11 & .04 \\
\hline & Non-E Major & 74 & 3.89 & 1.14 & .13 & \\
\hline \multirow[t]{2}{*}{ Teasing } & E-Majored & 84 & 3.58 & .95 & .10 & .00 \\
\hline & Non-E Major & 74 & 4.08 & 1.02 & .12 & \\
\hline \multirow[t]{2}{*}{ Banter } & E-Majored & 84 & 3.13 & 1.19 & .13 & .43 \\
\hline & Non-E Major & 74 & 3.30 & 1.43 & .17 & \\
\hline \multirow[t]{2}{*}{ Language play } & E-Majored & 84 & 4.01 & .83 & .09 & .02 \\
\hline & Non-E Major & 74 & 4.31 & .78 & .09 & \\
\hline \multirow[t]{2}{*}{ Joke } & E-Majored & 84 & 4.36 & .67 & .07 & .33 \\
\hline & Non-E Major & 74 & 4.47 & .82 & .10 & \\
\hline \multirow[t]{2}{*}{ Riddles } & E-Majored & 84 & 3.98 & .89 & .10 & .16 \\
\hline & Non-E Major & 74 & 4.19 & 1.02 & .12 & \\
\hline \multirow[t]{2}{*}{ Visual humor } & E-Majored & 84 & 3.48 & 1.14 & .12 & .00 \\
\hline & Non-E Major & 74 & 4.00 & 1.10 & .13 & \\
\hline \multirow[t]{2}{*}{ Physical humor } & E-Majored & 84 & 3.58 & .98 & .11 & .04 \\
\hline & Non-E Major & 74 & 3.92 & 1.10 & .13 & \\
\hline \multirow[t]{2}{*}{ Total } & E-Majored & 84 & 3.71 & .65 & .07 & .01 \\
\hline & Non-E Major & 74 & 4.02 & .79 & .09 & \\
\hline
\end{tabular}

The test results revealed that the nonEnglish major students preferred the proposed types of teacher humor more than the majored students did in general (Mnon-English=4.02; Mmajored=3.71; $p=.01$ ). In other words, EFL teachers should use teacher humor strategies in non-English major classes rather than using them in English-majored classes.

The findings from the interviews also strengthened the conclusion that non-majored and majored students perceived the potentials of teacher humor in their EFL classes differently. While the non-majored students were highly delighted when talking about teacher humor, the majored ones seemed to have some doubts about its advantages to help them reach their future dreams. Specifically, Student $F$ representing non-majored students optimistically shared,
"Honestly, my demands on English learning are not really high. So, I do not need to learn a lot and just want to have some fun as well as get some new vocabulary. That's it! I do not find any inconvenience when my teacher tells funny stories; even I really love them." (F; Female; NonEnglish Major Student; $M=4.85$ )

In reverse, a representative for Englishmajored students, Student B stated,

"In spite of understanding the benefits of $\mathrm{TH}$, I sometimes feel uncomfortable because it distracts my concentration on the lessons. Therefore, I'm afraid that my teacher does not have enough time to deliver all the knowledge I need for my future job." (B; Female; EnglishMajored Student; $M=3.89$ )

Laguador (2013) stated that in-class activities must address students' needs to help them achieve their goals after graduating from university. Compared to non-majored students, the majored ones' expectation of the 
effectiveness of their teachers' instructions could be much higher. As a result, they would like to stay focused on learning rather than finding something funny. On the other hand, non-majored students seemed to be not under high pressure since English is not their primary tool for their future jobs.

Besides, the test results show some differences and similarities in students' preferable types of teacher humor. Specifically, non-English major and majored students perceived banter, joke, and riddles at the same level ( $p>05)$.

First, both English-majored and non-English major students disliked the type of banter (Mnon-English=3.30; Mmajored=3.13; $\mathrm{p}=.43$ ) because they were afraid that their teachers might cause misunderstandings or unexpected bad situations. Students C and G said,

"I do not want to observe the misunderstandings in the classrooms. I used to face such a situation that I teased my friend, made him look a bit silly just for fun. However, he got hurt. Therefore, I really do not want my teachers to face that situation. They should be careful." (C; Male; English-Majored Student; M=2.68)

"Teachers should not use banter because it easily causes unexpected bad situations. Moreover, I do not like hearing these aggressive utterances." (G; Male; Non-English Major Student; $M=3.21$ )

Technau (2017) said the banter mentioned above is a risk-taking behavior. Banter might become worthless when the beneficiary does not acknowledge the hidden good meanings (Fadel \& Al-Bargi, 2018).

Second, the type of joke was most favored among all proposed types of teacher humor by both English-majored and non-English major students in the current study (Mnon-
English=4.47; Mmajored=4.36; $p=.33$ ). Students $\mathrm{D}$ and $\mathrm{F}$ remarked on the benefits of jokes as follows,

"Sometimes, my teacher tells some jokes to make the class less boring. Even though I am a serious person, finding something funny is not a bad idea, right?" (D; Male; English-Majored Student; $\mathrm{M}=4.01$ )

"It is very interesting when listening to my teacher talking about his learning experience with some jokes. The classroom atmosphere is better." (F; Female; Non-English Major Student; $M=4.85$ )

Petraki and Nguyen (2016) also investigated the same findings that lightening the classroom atmosphere or increasing the teachers' immediacy is why Vietnamese teachers use jokes in English classes.

Third, both English-majored and non-English major students were remarkably perceived to riddles as their preferable type of teacher humor (Mnon-English=4.19; Mmajored=3.98; $\mathrm{p}=.16)$. Students $\mathrm{B}$ and $\mathrm{F}$ shared,

"I like playing word games because they are so funny. I still remember that it took my class a day to answer the question, "what has four wheels and flies?". The answer will surprise you, I promise. It is "A garbage truck." So funny, right?" (B; Female; English-Majored Student; $M=3.89$ )

"It is very interesting to play....what do we call it? Riddles, right? We have to answer the question in a humorous way. For example, I have a question for you, "How can you survive in the desert?" What is your answer? 30 seconds for you!!! [...] You lose. The answer is "By eating sand-which." It is one of a lot of questions my teacher used in my class." (F; Female; Non-English Major Student; $M=4.85$ )

Kim and Park (2020) also found that Korean EFL students showed positive attitudes towards using word games in EFL classes. According to Maranda (1976), riddles are often used to test one's acuity, intelligence, and skills. Therefore, 
it leads to the feeling of conquering challenges to avoid losing face. McCall (1997) claimed that the motivation to conquer challenges is mastery motivation, a must-have to tackle new tasks.

Besides the similarities, there were some differences according to the students' preferable types of teacher humor, including irony, teasing, language play, visual an d physical humor $(P<.05)$.

According to the interview findings, the English-majored students seemed unhappy with the teacher's irony because they felt their teachers were playing their feelings. Student A said,

"My teacher often says, "You good! You good!" like a sarcasm whenever I give wrong answers to his questions. It is very uncomfortable." ( $A$; Female; English-Majored Student; M=1.63)

On the other hand, the non-English major students did not give harsh comments to this type of teacher humor. Student H shared,

"When I answer incorrectly, my teacher often says, "What an excellent answer! Good, you! Nevertheless, the answer is wrong." I know that the compliment is not true because I am good at English at all. However, the classroom atmosphere is great, and I do not think it hurts me. It is okay for me because my friends are the same at my level. We are the same!!! *Laugh*." (H; Male; Non-English Major Student; $M=5.00$ )

According to Colston and O'Brien (2000), ironic messages can benefit from being humorous. However, using irony is not without risk (Staunton et al., 2020). As explained, the use of irony will be challenged if the receivers are not interested and sufficiently engaged with the messages.

In terms of teasing, the English-majored students seemed to have high ego and self- confidence in their English proficiency. Therefore, they might render teasing disparaging. Student A remarked,

"I do not like my teacher's teasing much. You know, I am an English-majored student, so English is absolutely what I am strongly confident in myself. When someone crosses the line of my ego in English, I cannot accept it." (A; Female; EnglishMajored Student; $M=1.63$ )

The sharing was similar to the study by Wanzer et al. (2006), which indicated that teasing learners receives disparaging remarks. They might feel uncomfortable engaging in such humor with higher-status people as their teachers.

On the other hand, the non-English major students compared themselves to other nonmajored friends and felt okay with teasing, or even they used to tease their friends in a suitable manner, not for bringing down others. Student F said,

"My English is not really good, so being teased by others, or even my teacher, is acceptable to me. *Laugh* I sometimes tease my friends when they make mistakes, and vice versa. I have accepted my "good English" for years. *Laugh*." (F; Female; Non-English Major Student; M=4.85)

Unlike the English-majored students, they overcame the negative feeling of losing face and gained benefits from teasing.

Although the quantitative results indicated the differences between English-majored and non-English major students' perceptions of the type of language play, most interviewees showed their positive attitudes towards this type. Students D and F stated,

"Do you know the tongue twister game? It is my favorite activity in English classes." (D; Male; English-Majored Student; $M=4.01$ ) 
"There is a language game that we have to read a short paragraph with a lot of " $\mathrm{B}$ " letters. It is very difficult to read correctly the paragraph. None of us can do it except the teacher. But it is nothing to disappoint because it is an exciting game to me. We have a lot of fun when playing this game. Moreover, I think it is useful for practicing pronunciation." (F; Female; Non-English Major Student; $M=4.85$ )

It aligned with the study by Lee (2017) which remarked on the potentials of language play on the improvement of EFL students' phonemic awareness. Playing such games as tongue twister required the students to practice and be aware of the phonetic aspects. Consequently, their pronunciation notably improved.

In terms of visual and physical humor, while the English-majored students expected their teachers' proficiency and professionalism, the non-English major ones wanted to have a comfortable learning atmosphere with their teachers. Student A said,

"I do not like my teachers looking and acting silly. In the future, I want to become an English teacher, so this profession is very noble to me. I do not want anyone to maculate this image in me." (A; Female; English-Majored Student; $M=1.63$ )

Otherwise, Student G remarked,

"Sometimes, my teacher uses funny gestures to reduce the boredom in the class, and this work is effective. Therefore, it is okay for me when my teacher does these things. It does not affect the professionalism at all, I think." (G; Male; NonEnglish Major Student; M=3.21)

According to Martin (2010), due to some drawbacks, including disparaging others, controlling and mocking nonconforming behaviors, exhibiting power or status differences, or suppressing undesired actions, EFL teachers often avoid using teacher humor in English classes. However, the current study showed a dependent finding that EFL teachers could use teacher humor when considering it.

\section{Conclusion}

In a nutshell, the three most preferable types of teacher humor were jokes, language play, and riddles. On the other hand, the most resisted type of teacher humor was banter. There was a significant influence of the students' backgrounds on their preferences of teacher humor in their English classes. Specifically, the male students showed more positive attitudes towards teacher humor than their counterparts. Moreover, the non-English major students preferred irony, teasing, language play, visual and physical humor than the majored ones in the current study.

Based on the current findings, there are many potentials of teacher humor in EFL classes, such as increasing instructional effectiveness, lowering students' anxiety, creating a relaxed classroom environment, motivating students in learning, improving students' learning, establishing collaborative teacher-student interaction, and even keeping students thinking. Therefore, EFL teachers should learn more about valuable strategies for using teacher humor in their classes.

Teacher humor can be successfully used in EFL classes when some aspects are considered. For example, EFL teachers are encouraged to use jokes, language play, and riddles due to the students' strong acceptance of these teacher humor types. However, EFL teachers should be careful when using particular types of teacher humor in their classes, especially banter. Many aspects to consider help EFL students understand teacher humor, including teacher intentions, teacher competencies, discursive 
roles, relational and conversational histories, rituals, specific context features, lexical information, and non-verbal cues. These aspects require the teachers to practice teacher humor before using it in their classes.

Furthermore, some teachers avoid using teacher humor because they lack a sense of humor. The query on if EFL teachers can use teacher humor in their classes even though they are not humorous has been discussed for a long time. However, the current study's proposed types of teacher humor can be designed by EFL teachers without any sense of humor. However, they have to understand what to use, how to use, and how to avoid misunderstanding in particular situations to maximise the potentials of teacher humor in EFL classes. Therefore, they can adapt the types of teacher humor in their lesson plans, such as language play or riddles. Moreover, there is a caution that the benefits of teacher humor can only be observed when the teachers use it to laugh with their students, not laugh at them.

Finally, further research should include the classroom observations to collect data, thus, making the results more significant. Additionally, the sampling should be recruited in all education levels, from kindergarten to postgraduate, in order to generalize the effects of teacher humor in English classes at all education levels.

\section{References}

AbdAli, A., Ashur, N., Ghazi, L., \& Muslim, A. (2016). Measuring Students' Attitudes towards Teachers' Use of Humour during Lessons: A Questionnaire Study. Journal of Education and Practice, 7(35), 52-59.
Apte, M. L. (1985). Humor and Laughter: An Anthropological Approach. Cornell University Press.

Baringer, D. K., \& McCroskey, J. C. (2000). Immediacy in The Classroom: Student Immediacy. Communication Education, 49(2), 178-186.

Bekelja Wanzer, M., Bainbridge Frymier, A., Wojtaszczyk, A. M., \& Smith, T. (2006). Appropriate and Inappropriate Uses of Humor by Teachers. Communication Education, 55(2), 178-196.

$\begin{array}{lll}\text { Bonacchi, } & \text { S. 2018). Verbal }\end{array}$ Aggression. In Handbuch Pragmatik (pp. 439-447). JB Metzler, Stuttgart.

Belz, J. A. (2002). Second Language Play as a Representation of the Multicompetent Self in Foreign Language Study. Journal of Language, Identity, and Education, 1(1), 1339.

Boxer, D., \& Cortés-Conde, F. (1997). From Bonding to Biting: Conversational Joking and Identity Display. Journal of Pragmatics, 27(3), 275294.

Colston, H. L., \& O'Brien, J. (2000). Contrast of Kind Versus Contrast of Magnitude: The Pragmatic Accomplishment of Irony and Hyperbole. Discourse Processes, 30(2), 179199.

Curnow, S. J., Falciani, F., Durrani, O. M., Cheung, C. G., Ross, E. J., Wloka, K., Rauz, S., Wallace, G. R., Salmon, M., \& Murray, P. I. (2005). Multiplex Bead Immunoassay Analysis of Aqueous Humor Reveals Distinct Cytokine Profiles in Uveitis. Investigative Ophthalmology \& Visual Science,46(11), 4251-4259. 
Dynel, M. (2009). Beyond A Joke: Types of Conversational Humour. Language and Linguistics Compass, 3(5), 1284-1299.

Englert, L. M. (2010). Learning with Laughter: Using Humor in The Nursing Classroom. Nursing Education Perspectives, 31(1), 48-49.

Fadel, S. A., \& Al-Bargi, A. (2018). The Use of Humour in EFL Classrooms: Comparative Conversational Analysis Case Study. Arab World English Journal (AWEJ), 9(2), 262-282.

Fki, N. (2021). Investigating Humor Integration in Tunisian Tertiary English Classes: A Comparative Study of Teachers' and Learners' Perceptions. Advances in Language and Literary Studies, 12(3), 127140.

Goatly, A. (2012). Meaning and Humour. Cambridge University Press.

Keltner, D., Capps, L., Kring, A. M., Young, R. C., \& Heerey, E. A. (2001). Just Teasing: A Conceptual Analysis and Empirical Review. Psychological Bulletin, 127(2), 229248.

Kim, S., \& Park, S. H. (2020). Types of Verbal Humor in Elementary English Classes in Korea. English Teaching, 75(4), 101-132.

Laguador, J. M. (2013). Developing Students' Attitude Leading Towards a Life-Changing Career. Educational Research International, 1(3), 28-33.

Lee, E. S. (2017). The Effects of Language Play Enhanced Activities (LPEA) in Novice EFL Classroom. 영어교육연구, 29(1), 21-42.

Liu, K. W. (2012). Humor Styles, Self-Esteem and Subjective Happiness. Humor, 1, 21-41.

Maranda, E. (1976). Riddles and Riddling: An Introduction. The Journal of American Folklore, 89(352), 127-137.
Martin, R. A. (2010). Approaches to the Sense of Humor: A Historical Review. In The Sense of Humor (pp. 15-60). De Gruyter Mouton.

McCall, R. B. (1995). On Definitions and Measures of Mastery Motivation. In R. H. MacTurk \& G. A. Morgan (Eds.), Mastery Motivation: Origins, Conceptualizations, and Applications (pp. 273-292). Ablex Publishing.

McCroskey, J. C., Richmond, V. P., \& Bennett, V. E. (2006). The Relationships of Student EndOf-Class Motivation with Teacher Communication Behaviors and Instructional Outcomes. Communication Education, 55(4), 403-414.

Moroschan, G., Hurd, P. L., \& Nicoladis, E. (2009). Sex Differences in the Use of Indirect Aggression in Adult Canadians?. Evolutionary Psychology, 7(2), 146-159.

Morrison, M. K. (2012). Using Humor to Maximize Living: Connecting with Humor. R\&L Education.

Neuliep, J. W. (1991). An Examination of the Content of High School Teachers' Humor in The Classroom and The Development of an Inductively Derived Taxonomy of Classroom Humor. Communication Education, 40(4), 343-355.

Norrick, N. R. (2003). Issues in Conversational Joking. Journal of Pragmatics, 35(9), 13331359.

Oxford, R. L. (1990). Language Learning StrategiesWhat Every Teacher Should Know. Heinle \& Heinle.

Petraki, E., \& Nguyen, H. H. P. (2016). Do Asian EFL Teachers Use Humor in The Classroom? A Case Study of Vietnamese EFL University Teachers. System, 61, 98-109. 
Schmitz, J.R. (2002). Humor as a Pedagogical Tool in Foreign Language and Translation Courses. Humor: International Journal of Humor Research, 15(1), 89-113.

Shade, R. A. (1996). License to Laugh: Humor in the Classroom. Libraries Unlimited.

Staunton, T. V., Alvaro, E. M., Rosenberg, B. D., \& Crano, W. D. (2020). Controlling Language and Irony: Reducing Threat and Increasing Positive Message Evaluations. Basic and Applied Social Psychology, 42(5), 369-386.

Tarone, E. (2005). Fossilization, Social Context and Language Play. In Studies of Fossilization in Second Language Acquisition (pp. 157-172). Multilingual Matters.

Technau, B. (2017). Aggression in Banter. In Verbale Aggression (pp. 89-122). De Gruyter.
Torok, S. E., McMorris, R. F., \& Lin, W. C. (2004). Is Humor an Appreciated Teaching Tool? Perceptions of Professors' Teaching Styles and Use of Humor. College Teaching, 52(1), 14-20.

Tuncay, H. (2007). Welcome to HELL: Humor in English Language Learning. Online Submission. Retrieved from http://www.eric.ed.gov/

Wanzer, M. B., Sparks, L., \& Frymier, A. B. (2009). Humorous Communication Within the Lives of Older Adults: The Relationships Among Humor, Coping Efficacy, Age, and Life Satisfaction. Health Communication, 24(2), 128-136. 
Pham Trut Thuy, Le Thanh Thao 